\begin{tabular}{r|l|l|l}
$\begin{array}{r}\text { Case Reports in } \\
\text { Gastunenterology }\end{array}$ & $\begin{array}{l}\text { Case Rep Gastroenterol 2010;4:524-527 } \\
\text { DOl: 10.1159/000322884 }\end{array}$ & $\begin{array}{l}\text { Published online: } \\
\text { December 4, 2010 }\end{array}$ & $\begin{array}{l}\text { O 2010 S. Karger AG, Basel } \\
\text { ISSN 1662-0631 } \\
\text { www.karger.com/crg }\end{array}$ \\
\hline
\end{tabular}

This is an Open Access article licensed under the terms of the Creative Commons AttributionNonCommercial-NoDerivs 3.0 License (www.karger.com/OA-license), applicable to the online version of the article only. Distribution for non-commercial purposes only.

\title{
Cecal Varices Presenting as Anemia: Case Report and Review of the Literature
}

\author{
Monica El-Masry Richard Hu \\ Department of Internal Medicine, Division of Gastroenterology, UCLA-Olive View \\ Medical Center, Sylmar, Calif., and David Geffen School of Medicine at UCLA, \\ Los Angeles, Calif., USA
}

\author{
Key Words \\ Varices · Portal hypertension $\cdot$ Cecum $\cdot$ Colon $\cdot$ Liver
}

\begin{abstract}
Since the original description of colonic varices in 1954 [N Engl J Med 1954;250:434-438], fewer than 100 cases have been reported in the literature. Particularly, even fewer cases of cecal varices have been reported. More than $75 \%$ of these cases have been due to portal hypertension. Our objective is to contribute a rare case with an uncommon presentation to the medical literature. We present the case of a 53-year-old male with hepatitis $C$ and hepatitis $B$ liver cirrhosis who presented for outpatient colonoscopy. The indication for colonoscopy was bright red blood per rectum and iron deficiency anemia. A significant amount of varices were noted in the cecum and proximal ascending colon. No endoscopic evidence of colonic bleeding was noted. This is the first reported case of cecal varices not presenting with massive lower gastrointestinal bleeding.
\end{abstract}

\section{Case Report}

A 53-year-old Caucasian male was evaluated for bright red blood per rectum with colonoscopy. The patient's past medical history was significant for end-stage liver disease due to hepatitis $\mathrm{C}$ and hepatitis B, asthma, and erythropoietic porphyria. The patient had prior episodes of hematemesis which required multiple sessions of esophageal variceal rubber band ligation treatment. He also had a remote history of rectal bleeding. At the time of evaluation the patient complained of bright red blood per rectum for a four month period without clinical evidence of active or massive bleeding. Family history was notable for colon cancer in the patient's father at age 60. His medications included propanolol, lasix, aldactone, lactulose, thiamine, and folate. Pertinent review of symptoms was negative for fevers, chills, weight loss, diarrhea, constipation, melena, weakness, or loss of consciousness.

Physical examination revealed a well-developed, well-nourished male in no acute distress appearing his stated age. Vitals signs were as follows: blood pressure $108 / 58 \mathrm{~mm} \mathrm{Hg}$, heart rate $66 / \mathrm{min}$, respiratory rate $18 / \mathrm{min}$, and temperature $36.9^{\circ} \mathrm{C}$. Head and oropharyngeal examinations were unremarkable. There was no scleral icterus. No cervical or supraclavicular lympadenopathy was palpated. The lungs were clear to auscultation bilaterally. Heart and neurologic examination were unremarkable. Abdominal 


\begin{tabular}{r|l|l|l} 
Case Reports in & $\begin{array}{l}\text { Case Rep Gastroenterol 2010;4:524-527 } \\
\text { DOl: 10.1159/000322884 }\end{array}$ & $\begin{array}{l}\text { Published online: } \\
\text { December 4, 2010 }\end{array}$ & $\begin{array}{l}\odot \text { ISSN 1662-0631 } \\
\text { www.karger.com/crg }\end{array}$ \\
\hline
\end{tabular}

examination revealed hepatomegaly to two inches below the costal margin and splenomegaly. In addition, abdominal examination revealed a $2 \times 2 \mathrm{~cm}$ umbilical hernia and a right-sided inguinal hernia. Skin examination revealed multiple spider angiomas on the chest. Extremity examination revealed trace pitting edema and $2+$ dorsalis pedis pulses. Rectal examination was notable for external hemorrhoids.

Recent complete blood count prior to colonoscopy revealed a hemoglobin of $11.5 \mathrm{~g} / \mathrm{dl}$, hematocrit of $34.6 \%$, and a platelet count of 36,000 with a MCV of 81.3 . The patient's INR was 1.4 and albumin 3.8. The patient had positive serologies proving both infection with hepatitis B and C. The patient's hepatitis $\mathrm{C}$ viral load was undetectable. Recent abdominal ultrasound was notable for hepatomegaly, nodular and heterogeneous in consistency, massive splenomegaly, and ascites. Colonoscopy was significant for internal hemorrhoids as well as cecal and proximal ascending colon varices without any endoscopic evidence of bleeding (fig. 1).

\section{Discussion}

Reported cases of varices have been found in the stomach, small bowel, biliary tree, colon, rectum, and even the site of a surgical ostomy [1-4]. The stomach and the rectum are the most common sites of extraesophageal varices and up to $30 \%$ of variceal bleeding may originate from an extraesophageal location [2]. A history of abdominal surgery may predispose a patient to develop varices of the lower gastrointestinal tract $[5,6]$. The most common cause of colonic varices is portal hypertension. Other causes include biliary atresia, biliary sclerosis, congestive heart failure, superior mesenteric vein thrombosis, and inferior mesenteric vein thrombosis. A smaller number are of idiopathic origin [7]. Due to the patient's history of esophageal varices as a result of portal hypertensive gastropathy, we also believe the cecal varices were the result of portal hypertension.

This case of cecal and ascending colon varices is presented because of the uniqueness of this anomaly within the colon and most notably the cecum. In the literature, a total of seventeen cases (including this one) of cecal varices have been reported [2, 5, 6, 8-20]. The cases of cecal varices that have been reported have all presented clinically with massive lower gastrointestinal bleeding necessitating urgent management with blood products and surgical or endoscopic intervention. To our knowledge this is the first case of cecal varices reported that has not resulted in massive lower gastrointestinal bleeding. This patient only presented with bright red blood with bowel movements and anemia. He did not demonstrate any episodes of massive gastrointestinal bleeding requiring immediate intervention as in the previous cases reported. Given the colonoscopic finding, we believe that the internal hemorrhoids and not the cecal varices may have contributed to his clinical presentation. By reporting our experience we emphasize that cecal varices are very rare and may also be present in stable patients without massive lower gastrointestinal bleeding.

Because of the paucity of data, the proper management of patients with colonic varices is unknown [7]. Treatment of cecal varices has included colectomy as well as transjugular portal-systemic shunt in cases of varices attributed to portal hypertension. There are no established guidelines for the treatment of extraesophageal varices due to the scarcity of cases reported. Our patient has been treated with a non-selective beta-blocker. He is clinically stable and has no clinical evidence indicating a history of active bleeding from those varices. However, further study is needed to determine whether sclerotherapy, band ligation, or even surgical treatment is effective for bleeding associated with cecal varices. Careful patient follow-up should also be instituted for those who are incidentally noted to have cecal varices but have not bled. 


\begin{tabular}{r|l|l|l}
$\begin{array}{r}\text { Case Reports in } \\
\text { Gastruanteriology }\end{array}$ & $\begin{array}{l}\text { Case Rep Gastroenterol 2010;4:524-527 } \\
\text { DOI: 10.1159/000322884 }\end{array}$ & $\begin{array}{l}\text { Published online: } \\
\text { December 4, 2010 }\end{array}$ & $\begin{array}{l}\text { O 2010 S. Karger AG, Basel } \\
\text { ISSN 1662-0631 } \\
\text { www.karger.com/crg }\end{array}$ \\
\hline
\end{tabular}

\section{Disclosure Statement}

There are no conflicts of interest.

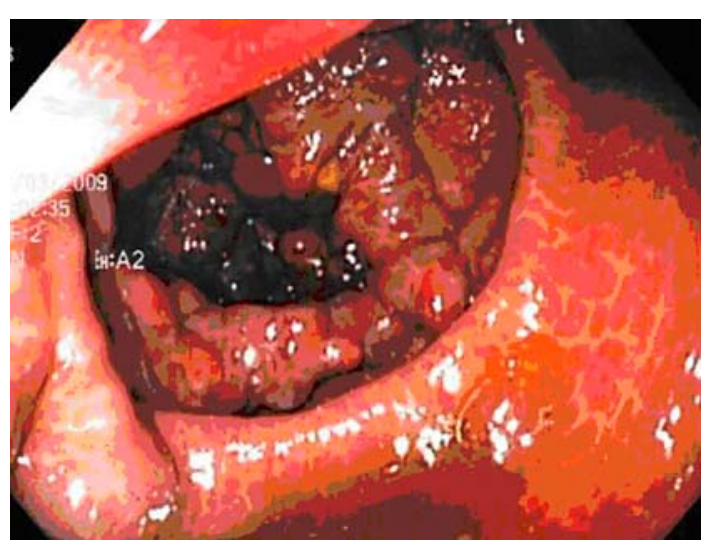

Fig. 1. Varices noted in the cecum.

\section{References}

1 Ganguly S, Sarin SK, Bhatia U, et al: The prevalence and spectrum of colonic lesions in patients with cirrhotic and noncirrhotic portal hypertension. Hepatology 1995;21:1226-1231.

2 Scandalis N, Archimandritis A, Kastunas K, et al: Colonic findings in cirrhotics with portal hypertension. A prospective colonoscopic and histological study. J Clin Gastroenterol 1994;18:325-328.

-3 Rabinovitz M, Schade RR, Dindzens VJ, et al: Colonic disease in cirrhosis. An endoscopic evaluation in 412 patients. Gastroenterology 1990;99:195-199.

4 Norton ID, Andrews JC, Kamath PS: Management of ectopic varices. Hepatology 1998;28:1154-1158.

5 Klein SD, Hellinger JC, Silverstein ML, et al: Isolated cecal varices as the source of massive lower GI bleeding in a patient with cirrhosis. Am J Gastroenterol 2003;98:220-221.

6 Hashmonai M, Kopelman D, Engel A, Assalia A: Acute gastrointestinal bleeding from caecal varicosities. Eur J Surg 2000;166:186-188.

7 Place RJ: Idiopathic colonic varices as a cause of lower gastrointestinal bleeding. South Med J 2000;93:11121114.

8 Shaper KR, Jarmulowicz M, Dick R, et al: Massive colonic haemorrhage from a solitary caecal varix. HPB Surg 1996;9:253-256.

-9 Sugiyama S, Yashiro K, Nagasako K, et al: Extensive varices of ileocecum. Report of a case. Dis Colon Rectum 1992;35:1089-1091.

10 Wilson SE, Stone RT, Christie JP, et al: Massive lower gastrointestinal bleeding from intestinal varices. Arch Surg 1979;114:1158-1161.

11 Mikat DM: Varices of the appendix and cecum. Am J Surg 1971;122:832-833.

12 Levy JS, Hardin JH, Shipp H, Keeling JH: Varices of cecum as an unusual cause of gastrointestinal bleeding. Gastroenterology 1957;33:637-640.

13 Bellaiche G, Nouts A, Brassier D, et al: Digestive hemorrhage due to rupture of the caecal varices in a patient with cirrhosis. Gastroenterol Clin Biol 1999;23:276-278. 
14 Komatsuda T, Ishida H, Konno K, et al: Color Doppler findings of gastrointestinal varices. Abdom Imaging 1998;23:45-50.

$\checkmark 15$ Bühler L, Tamigneaux I, Giostra E, et al: Ectopic varices, a rare cause of digestive hemorrhage. Schweiz Med Wochenschr Suppl 1996;79:70S-72S.

16 Gudjonsson H, Zeiler D, Gamelli RL, et al: Colonic varices. Report of an unusual case diagnosed by radionuclide scanning, with review of the literature. Gastroenterology 1986;91:1543-1547.

17 Barry JW, Engle CV: Detection of hemorrhage in a patient with cecal varices using $99 \mathrm{mTc}$-sulfur colloid. Radiology 1978;129:489-490.

-18 Iredale JP, Ridings P, McGinn FP, et al: Familial and idiopathic colonic varices: an unusual cause of lower gastrointestinal haemorrhage. Gut 1992;33:1285-1288.

19 Arvanitakis C: Localization of bleeding vascular lesions in the gastrointestinal tract. Wis Med J 1973;72: 139-140.

20 Patel KR, Wu TK, Powers SR: Varices of the colon as a cause of gastrointestinal haemorrhage. Dis Colon Rectum 1979;22:321-323. 